\title{
Sewage Water Quality of Phnom Penh City
}

\author{
Tomonori TAKEUCHI*,Yukio TAKAHASHI**, and Chea SINA*** \\ * Cambodia Environmental Research Group, 8050 Ikarashi 2-cho, Niigata City, Niigata Prefecture, Japan, e-mail: \\ totake29@hotmail.com \\ ** Department of Engineering, Niigata University, 8050 Ikarashi 2-cho, Niigata City, Niigata Prefecture, Japan, e-mail: \\ yukitak@eng.niigata-u.ac.jp \\ *** Ministry of Environment Cambodia, \#48, Samdech Preah Sihanouk Tonle Bassac, Phnom Penh, Cambodia
}

\begin{abstract}
Sewage water quality from Phnom Penh City in Cambodia was studied from December 1997 to September 1999. Samples were collected from the outfalls of sewer pipes to Tonle Sap River, channels, lakes, and pumping stations.

As a result, concentrations of chemical oxygen demand (COD), total nitrogen (T-N) and total phosphorus (T-P) in dry season were much higher than those of surface water in Cambodia possibly due to the domestic wastewater. In rainy season, these amounts decreased due to attenuation by the rainwater. In dry season, $56 \%$ of suspended solid (SS) in sewage deposited as sediments in channels and lakes. The levels of $\mathrm{Cd}, \mathrm{Zn}, \mathrm{Cu}$ and $\mathrm{Pb}$ in the sediments of these channels and lakes were higher than those in other points of the area studied. In rainy season, SS and heavy metals were flushed outside by the rainwater. Levels of anionic and nonionic surfactants, total organic halogen (TOX) and Bisphenol-A were found to those in Japan. Both surfactants mainly came from domestic wastewater while TOX and Bisphenol-A came from specific emission sources. Daily pollutant loads of SS, COD, T-N, T-P, anionic surfactant and nonionic surfactant were 13, 53, 8.2, 1.1, 1.4 and 0.3 (g/person-day), respectively.
\end{abstract}

\section{KEYWORDS \\ Sewage water quality; Phnom Penh; Cambodia}

\begin{abstract}
INTRODUCTION
\section{Purpose}

Water pollution caused by untreated wastewater is one of the serious problems that confront most developing countries (Kwai et al.1991). In Phnom Penh City, the capital of Cambodia, all kinds of wastewater are discharged to rivers, lakes and wetlands throughout the city without proper treatment causing serious surface water pollution. Water testing is an essential factor to control water pollution. However, water quality data and water quality testing systems are still poorly developed in Cambodia due to lack of facilities and technical expertise. Therefore, there is no information available on sewage water quality in Phnom Penh City. In this study, we investigated the quality of sewage water discharged from Phnom Penh City in dry and rainy seasons.
\end{abstract}

\section{Sewage Management in Phnom Penh city}

Cambodia is situated in Southeast Asia with a total geographical area of approximately $181,000 \mathrm{~km}^{2}$ and a population of 11.4 million (Cambodia National Census, 1998 - Figure 1). The climate is under tropical monsoon with rainy season from May to October and dry season from November to April. Cambodia has two major rivers, namely, Mekong River and Tonle Sap River. Phnom Penh lies on a flat flood plain developed at the confluence of both major rivers. Phnom Penh covers a surface of $284 \mathrm{~km}^{2}$, and is inhabited by 1,070,000 people (Asia Development Bank, 1997). Phnom Penh consists of seven districts, but can be divided into two areas: one is an urbanized area protected by dikes and the other is a suburbanized area outside the dikes. Road network is allocated as a grid system, and water and electric power supply systems exist in urbanized area, but they were remarkably damaged during the long conflict in the country. Recently, a variety of international agencies have been rehabilitating the infrastructures. Residential and commercial areas have developed and a lot of industrial buildings are scattered in the urbanized area. In contrast, water and electric power supplies are distributed only along national roads in 


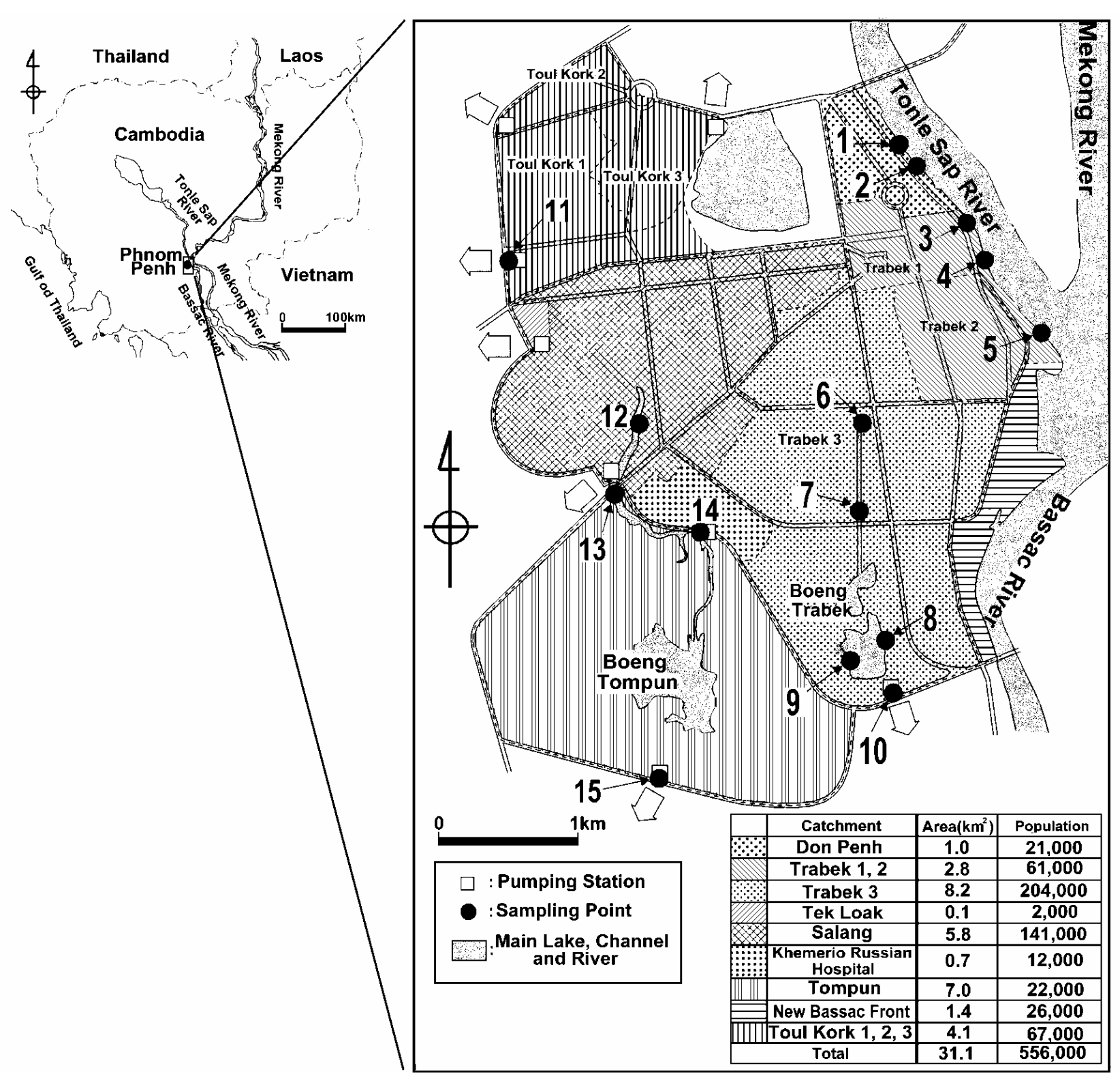

Figure 1. Study area and sampling point

the suburbanized area. Wetlands, ponds and communities are scattered in this area. The urbanized area is about $10 \%\left(31 \mathrm{~km}^{2}\right)$ of the whole Phnom Penh area where approximately 600,000 people $(60 \%$ of the whole Phnom Penh population), live (Asia Development Bank, 1998). All kinds of wastewater from the urbanized area are collected by gravity together with storm water through sewers, channels and ditches, and discharged over the dike through pumping stations. The sewer pipe network in the urbanized area is allocated under the main street. As shown in Figure 1, drainage system in the urbanized area is divided into 7 main catchments. This study targeted these 7 catchments and Tompun catchment. Tompun catchment, although located in the suburbanized area, has been urbanizing recently and is also protected by the dike. Trabek catchment as well as Toul Kork catchment is divided into three small catchments. In dry season, wastewater from Don Penh, Trabek 1 and 2, and New Bassac Front are directly discharged to Tonle Sap River through the sewer. When the water level of Tonle Sap River becomes higher than the ground level of Phnom Penh City in rainy season, the outfalls of the sewer pipes on Tonle Sap River are closed and sewage is gathered and discharged to Boeng Trabek Lake. This lake serves as a retention lake. However, drainage in rainy season is not carried out smoothly so flood is frequent in the city. On the other hand, wastewaters from other catchments are flowed to ponds around the pumping stations, which are constructed in each catchment, through gravity sewers, ditches and channels in both seasons. Pond waters are then pumped and discharged into outside of the dike through the pumping station. The wastewaters discharged from Salang, Khmerio Hospital and Tek Loak catchments finally reached the Boeng Tompun Lake, which lies in 
Tompun catchment. Boeng Tompun Lake also received its own sewage from Tompun catchment. Therefore, the Boeng Tompun Lake receives the sewage discharged from 4 catchments $\left(13.6 \mathrm{~km}^{2}\right.$ and 177,000 people). The water in Boeng Tompun Lake is discharged into outside of the dike through its own pumping station. Construction of this drainage system started during the colonial period and was developed according to the extension of the city. The present network had been completed in the early 70's. The network, however, has not been maintained for a long time due to conflict. Thus, the sewers severely deteriorated. There is no sewage water treatment plant in Phnom Penh. Some buildings have a three-chamber septic tank but they also have not been maintained for a long period thereby lost their function (Ministry of Environment, Kingdom of Cambodia, 1994). Therefore, all kinds of wastewater are discharged to bodies of water all throughout Phnom Penh City without proper treatment. Squatter houses were built along the lakes, channels and rivers into which the wastewater and solid waste from these residences are directly discharged. Since the sewage are nutrient rich, aquaculture and fishing are carried out in the lakes. The Phnom Penh inhabitants then consume the crops and fishes grown in this lake resulting to a small food chain in Phnom Penh City.

\section{METHODS}

\section{Sampling}

Sampling point locations (1 to 15) are shown in Figure 1. In order to evaluate the difference of sewage water quality between the dry season and rainy season, samplings were carried out from 23rd to 27th of December 1997 in dry season and from 27th to 30th of September 1998 in rainy season. Sampling points 1 to 5 were at the outfalls of the sewer adjoining the Tonle Sap River. Points 6 to 10 were located at the channel and Beong Trabek Lake. The wastewater flowed down from point 6 to 10 by gravity. The width of the channel, where points 6 and 7 were located, is approximately $3 \mathrm{~m}$. Point 10 was at the pumping station. Points 12 and 13 were located at the edge of Salang Lake. The lake is long and narrow as shown in Figure 1, thus, it is shaped like a river. The sewage flowed down from point 12 to point 13. Points 11, 14 and 15 were also at the pumping stations. Samples were taken from all 15 points in dry season while 10 samples were taken from points 1 to 4, 7, 10-12, 14 and 15 in rainy season. During rainy season, the other 5 points $(5,6,8,9$ and 13) were difficult to access and samples were difficult to collect due to the elevated water level caused by rainwater. The outfalls along the Tonle Sap River are generally closed during rainy season. Points 1 to 4, however, were open because the water level of the Tonle Sap River was not high enough to be closed. The sediment samples were collected from all sampling points only once in dry season. It did not rain during the sampling in December 1997. On the other hand, it rained heavily every night during the sampling in rainy season except for the night of 30th September, which was just before the sampling in point 4 . The color of sewage in all points was black during the dry season survey, and foam formed around the pumping station. The flow velocities in rainy season were faster than those in the dry season at all points due to the rainwater.

\section{Analytical Method}

For water samples, 14 water quality indicators and 8 heavy metals were determined. On the other hand, volatile total solid (VTS) and 8 heavy metals were analyzed in sediment samples. Indicators and heavy metals in water and sediments were measured following the Japanese Sewage Water Testing Methods (Japan Sewage Works Association, 1997). Temperature, pH, transparency and dissolved oxygen (DO) were immediately measured at the sampling point after the samples were taken. All samples were taken to Japan near-freezing temperature and the rest of the analyses were performed. Total organic halogens (TOX) was measured by electric coulometry with Mitsubishi Kasei TOX-10 $\Sigma$. Prior to TOX measurement, all samples were filtered by 5C paper to avoid clogging the activated carbon-packed adsorption glass column. Bisphenol-A, which is one of the endocrine disrupters, was measured by gas chromatograph mass spectrophotometer (QP-5000, Shimazdu, Japan). Analytical procedure was based on the Interim Investigation Manual prepared by the Environment Agency, Japan (Environment Agency, Japan, 1998). Sediment samples were air-dried and screened using 2-mm sieve. After screening, samples were decomposed using $\mathrm{HNO}_{3}$ and $\mathrm{HCl}$ in a sealed decomposition vessel and heavy metals in solution 
were measured through Shimadzu ICPS-7500.

\section{RESULTS AND DISCUSSION}

The results of the analyses of the sewage samples collected in dry season and rainy season are summarized in Table 1.

Table 1. Summary of sewage water quality in Phnom Penh

\begin{tabular}{|c|c|c|c|c|c|c|c|c|}
\hline & \multicolumn{4}{|c|}{$\begin{array}{c}\text { December } 1997 \text { (Dry Season) } \\
\mathrm{n}=15\end{array}$} & \multicolumn{4}{|c|}{$\begin{array}{c}\text { September } 1998 \text { (Rainy Season) } \\
n=10\end{array}$} \\
\hline & Max & Min & Mean & $\sigma$ & $\operatorname{Max}$ & Min & Mean & $\sigma$ \\
\hline Temperature $\left({ }^{\circ} \mathrm{C}\right)$ & 34.7 & 26.3 & 30.0 & 2.46 & 28.3 & 25.4 & 26.7 & 1.08 \\
\hline Water Temperature $\left({ }^{\circ} \mathrm{C}\right)$ & 31.2 & 25.3 & 29.0 & 1.45 & 27.5 & 26.0 & 26.6 & 0.56 \\
\hline $\mathrm{pH}$ & 7.6 & 6.9 & 7.3 & 0.22 & 7.6 & 7.1 & 7.4 & 0.15 \\
\hline $\mathrm{EC}(\mu \mathrm{S} / \mathrm{cm})$ & 1,590 & 839 & 1,094 & 219 & 1,055 & 442 & 638 & 179 \\
\hline Transparency $(\mathrm{cm})$ & 13.9 & 1.9 & 5.9 & 3.24 & 4.9 & 1.5 & 3.0 & 0.90 \\
\hline $\mathrm{SS}(\mathrm{mg} / \mathrm{L})$ & 757 & 2.7 & 95 & 73.3 & 212 & 19 & 76 & 71.3 \\
\hline $\mathrm{DO}(\mathrm{mg} / \mathrm{L})$ & - & - & - & - & 5.4 & 0.8 & 2.1 & 1.33 \\
\hline $\mathrm{COD}(\mathrm{Cr})(\mathrm{mg} / \mathrm{L})$ & 475 & 67 & 200 & 141 & 223 & 36 & 62 & 57.1 \\
\hline $\mathrm{T}-\mathrm{N}(\mathrm{mg} / \mathrm{L})$ & 65 & 23 & 41 & 13.0 & 55 & 12 & 18 & 13.1 \\
\hline $\mathrm{T}-\mathrm{P}(\mathrm{mg} / \mathrm{L})$ & 9.5 & 3.3 & 5.6 & 2.04 & 5.9 & 1.0 & 2.0 & 1.44 \\
\hline Anionic Surfactant (mg/L) & 17 & 2.5 & 8.2 & 3.80 & 7.0 & 0.2 & 2.0 & 2.14 \\
\hline Nonionic Surfactant $(\mathrm{mg} / \mathrm{L})$ & 5.0 & 0.1 & 1.4 & 1.31 & 0.9 & N.D. & 0.3 & 0.32 \\
\hline $\mathrm{BPA}(\mu \mathrm{g} / \mathrm{L})$ & 0.185 & 0.015 & 0.081 & 0.05 & 0.660 & 0.020 & 0.158 & 0.20 \\
\hline $\operatorname{TOX}(\mu \mathrm{g} / \mathrm{L})$ & 20,700 & 28 & 1,627 & 5,280 & 143 & 19 & 45 & 38 \\
\hline $\mathrm{Cr}(\mu \mathrm{g} / \mathrm{L})$ & 47 & 1.0 & 9.4 & 12.1 & 14 & N.D. & 4.3 & 5.39 \\
\hline $\mathrm{Cu}(\mu \mathrm{g} / \mathrm{L})$ & 131 & 3.7 & 33 & 39.0 & 18 & 2.2 & 7.5 & 5.47 \\
\hline $\mathrm{Cd}(\mu / \mathrm{L})$ & 21 & 0.8 & 3.2 & 5.05 & 7.4 & 0.1 & 4.0 & 2.14 \\
\hline $\mathrm{Pb}(\mu \mathrm{g} / \mathrm{L})$ & 79 & N.D. & 17 & 20.5 & 39 & 7 & 18 & 8.78 \\
\hline $\mathrm{Zn}(\mu \mathrm{g} / \mathrm{L})$ & 668 & 12 & 131 & 192 & 250 & 114 & 165 & 41.5 \\
\hline $\operatorname{Mn}(\mu \mathrm{g} / \mathrm{L})$ & 1,123 & 205 & 449 & 274 & 454 & 207 & 337 & 78.1 \\
\hline $\mathrm{Fe}(\mathrm{mg} / \mathrm{L})$ & 5.8 & 0.3 & 1.8 & 1.65 & 8.4 & 1.0 & 3.3 & 2.77 \\
\hline $\mathrm{Mg}(\mathrm{mg} / \mathrm{L})$ & 18 & 6.9 & 11 & 3.75 & 12 & 5.7 & 8.4 & 2.02 \\
\hline
\end{tabular}

\section{Sewage under Dry Weather and the Attenuation by Rainwater}

Sewage from the study area is discharged together with rainwater. Therefore, attenuation by rainwater seemed to affect the sewage water quality. Average annual rainfall in Phnom Penh was 1,204 mm between 1988 and 1997. Most of annual rainfall, however, occur during rainy season. Monthly rainfall averages in Phnom Penh in December 1997 and September 1998 were 8 and 233 mm, respectively (Japan International Cooperation Agency, 1998). Thus, the total rainfall of December 1997 and September 1998 in the study area were given as $7.21 \times 10^{6}$ and $0.25 \times 10^{6} \mathrm{~m}^{3}$, respectively. On the other hand, water consumption and sewage flow in Phnom Penh were unknown to the authorities involved. Therefore, a survey on water consumption was conducted in September 1999. The maximum, minimum and average daily water consumption per capita were 330,89 , and $178 \mathrm{~L}$, respectively. The daily water supply in the main cities of Japan was 325 - 468 L/person (Japan Sewage Works Association, 2001). Thus, the water consumption of Phnom Penh was remarkably lower than that of Japan. The difference might be due to the widespread use of washing machines and bathtubs in Japan in contrast to Cambodia where these are not so prevalent. The population in the target area was $5.56 \times 10^{6}$ so the daily and monthly water consumptions in the study area were given as $0.1 \times 10^{6}$ and $3.1 \times 10^{6} \mathrm{~m}^{3}$, respectively. The amount of industrial and commercial water consumptions were not certain in this survey. The estimated daily water consumption, however, was almost similar to $0.12 \times 10^{6} \mathrm{~m}^{3}$ /day of the water supply capacity in Phnom Penh. Therefore, the estimated water consumption seemed to be correct. Assuming that $90 \%$ of water consumption was collected as sewage, monthly sewage flow in the 
study area was given as $2.8 \times 10^{6} \mathrm{~m}^{3}$. Rainfall in December 1997 was approximately one-tenth of sewage flow and that in September 1998 was 2.6 times that of sewage flow. This suggests that the samples collected in December 1997 were not greatly affected by the rainwater. In particular, points 1 to 5 seemed to receive almost the dry weather sewage because the sewage directly reached these points through sewer.

\section{Correlation Coefficients among Indicators}

Correlation coefficients among indicators in each season are shown in Table 2. Correlation coefficients for dry season were calculated without the results of the samples taken from point 8 because most indicators at this point showed extremely high values. The high correlation coefficients were observed among SS, $\mathrm{COD}(\mathrm{Cr}), \mathrm{T}-\mathrm{N}$ and T-P in dry season. Generally, these indicators had positive correlation with $\mathrm{Cu}, \mathrm{Cd}, \mathrm{Pb}, \mathrm{Zn}$, $\mathrm{Fe}$, anionic surfactant (AS), nonionic surfactant (NS) and Bisphenol-A (BPA). In rainy season, the correlation coefficients among COD, T-N, T-P, AS and NS were also high. Correlation coefficients among SS, $\mathrm{Cr}, \mathrm{Cd}, \mathrm{Pb}$, $\mathrm{Zn}$ and $\mathrm{Fe}$ are positive but when these indicators were paired with COD, T-N, T-P, AS, NS and BPA, negative coefficients resulted.

Table 2. Correlation coefficients between the indicators of Sewage

$<$ Dry Season (December 1997) $>$

\begin{tabular}{|c|c|c|c|c|c|c|c|c|c|c|c|c|c|c|c|c|c|}
\hline & $\mathrm{COD}$ & T-N & T-P & TOX & AS & NS & BPA & $\mathrm{Cr}$ & $\mathrm{Cu}$ & $\mathrm{Cd}$ & $\mathrm{Pb}$ & $\mathrm{Zn}$ & $\mathrm{Mn}$ & $\mathrm{Fe}$ & $\mathrm{Mg}$ & \\
\hline & & \multirow[t]{2}{*}{0.922} & 0.637 & 0.721 & 0.605 & 0.716 & 0.645 & 0.669 & 0.395 & 0.632 & 0.530 & 0.603 & 0.582 & 0.295 & 0.588 & 0.298 & SS \\
\hline & & & 0.776 & 0.871 & 0.575 & 0.769 & 0.617 & 0.667 & 0.417 & 0.685 & 0.511 & 0.658 & 0.665 & 0.229 & 0.611 & 0.277 & $\mathrm{COD}$ \\
\hline $\mathrm{COD}$ & -0.085 & & & 0.821 & 0.487 & 0.707 & 0.564 & 0.619 & 0.534 & 0.731 & \begin{tabular}{|c|}
0.483 \\
\end{tabular} & 0.668 & 0.650 & 0.040 & 0.631 & 0.150 & T-N \\
\hline T-N & -0.152 & 0.989 & & & 0.274 & 0.591 & 0.401 & 0.672 & \begin{tabular}{l|}
0.585 \\
\end{tabular} & 0.728 & 0.525 & 0.732 & 0.746 & 0.131 & 0.611 & \begin{tabular}{|l|}
0.119 \\
\end{tabular} & T-P \\
\hline T-P & -0.182 & 0.917 & 0.959 & & & 0.644 & 0.769 & 0.454 & 0.122 & 0.266 & \begin{tabular}{|c|}
0.138 \\
\end{tabular} & \begin{tabular}{|c|}
0.217 \\
\end{tabular} & 0.152 & -0.044 & 0.212 & \begin{tabular}{l|}
0.585 \\
\end{tabular} & TOX \\
\hline TOX & \begin{tabular}{|c|}
0.182 \\
\end{tabular} & 0.942 & 0.896 & 0.806 & & & 0.534 & 0.411 & 0.284 & 0.436 & 0.404 & 0.371 & 0.323 & 0.292 & 0.458 & 0.299 & A. $\mathrm{S}$. \\
\hline $\mathrm{AS}$ & -0.171 & 0.982 & 0.963 & 0.859 & 0.904 & & & 0.292 & 0.092 & 0.317 & 0.168 & 0.292 & 0.259 & 0.050 & 0.313 & 0.498 & N. S. \\
\hline NS & -0.204 & 0.670 & 0.695 & 0.743 & 0.564 & 0.642 & & & 0.822 & 0.816 & 0.655 & 0.808 & 0.771 & 0.053 & 0.686 & 0.104 & BPA \\
\hline BPA & 0.001 & 0.309 & 0.320 & 0.415 & 0.267 & 0.257 & 0.858 & & & 0.866 & 0.851 & 0.884 & 0.838 & 0.299 & 0.825 & 0.093 & $\mathrm{Cr}$ \\
\hline $\mathrm{Cr}$ & 0.967 & 0.103 & 0.029 & -0.009 & 0.367 & 0.008 & \begin{tabular}{|l|}
0.009 \\
\end{tabular} & 0.182 & & & 0.878 & 0.987 & 0.976 & 0.377 & 0.934 & 0.163 & $\mathrm{Cu}$ \\
\hline $\mathrm{Cu}$ & 0.714 & 0.560 & 0.465 & 0.330 & 0.775 & 0.508 & 0.152 & 0.057 & 0.814 & & & 0.884 & 0.846 & 0.714 & 0.966 & 0.279 & $\mathrm{Cd}$ \\
\hline $\mathrm{Cd}$ & 0.851 & -0.208 & -0.251 & -0.187 & 0.083 & -0.329 & -0.172 & 0.107 & 0.834 & 0.496 & & & 0.989 & 0.404 & 0.922 & 0.177 & $\mathrm{~Pb}$ \\
\hline $\mathrm{Pb}$ & 0.842 & 0.092 & -0.030 & -0.152 & 0.392 & 0.054 & -0.097 & 0.044 & 0.888 & 0.846 & 0.711 & & & 0.374 & 0.897 & 0.128 & $\mathrm{Zn}$ \\
\hline $\mathrm{Zn}$ & 0.812 & 0.232 & 0.174 & 0.171 & 0.490 & 0.117 & 0.015 & 0.025 & 0.850 & 0.814 & 0.738 & 0.776 & & & 0.632 & 0.443 & $\mathrm{Mn}$ \\
\hline $\mathrm{Mn}$ & -0.170 & 0.508 & 0.477 & 0.358 & 0.501 & 0.580 & 0.172 & -0.036 & -0.093 & 0.234 & -0.122 & 0.068 & -0.212 & & & 0.262 & $\mathrm{Fe}$ \\
\hline $\mathrm{Fe}$ & 0.842 & -0.220 & -0.287 & -0.241 & 0.032 & -0.308 & -0.050 & 0.335 & 0.842 & 0.479 & 0.862 & 0.742 & 0.638 & -0.249 & & & \\
\hline $\mathrm{Mg}$ & -0.244 & 0.183 & 0.242 & 0.214 & 0.091 & 0.220 & -0.011 & -0.261 & -0.275 & -0.156 & -0.163 & -0.349 & -0.357 & 0.664 & -0.491 & & \\
\hline & SS & $\mathrm{COD}$ & T-N & T-P & TOX & A. S. & N.S. & BPA & $\mathrm{Cr}$ & $\mathrm{Cu}$ & $\mathrm{Cd}$ & $\mathrm{Pb}$ & $\mathrm{Zn}$ & $\mathrm{Mn}$ & $\mathrm{Fe}$ & & \\
\hline
\end{tabular}

AS: Anionic Surfactant, NS: Nonionic Surfactant, BPA: Bisphenol-A

\section{Suspended Solid (SS)}

The results of SS analysis are shown in Figure 2. The maximum, minimum and mean values of SS in points 1 to 5 during dry season were 121, 51 and $90 \mathrm{mg} / \mathrm{L}$, respectively. Extremely high concentration of SS was found in point 8 . Since point 8 was located in the narrowest place of the lake, debris and solid wastes were deposited there so high concentration of SS resulted. The maximum, minimum and mean values of SS in other points during dry season were 49, 2.7 and $31 \mathrm{mg} / \mathrm{L}$, respectively. The concentrations of SS in points 1 to 5 were significantly higher than those in the other points. Points 1 to 5 directly received the sewage from each source through the sewers while the other points received sewage through the open channels and lakes. Suspended solids in sewage had deposited during the flow through the channels and lakes resulting to lower SS concentrations. Mean value of SS in points 6 to15, except for point 8 , was $34.4 \%$ of that of points 1 to 5 so $65.6 \%$ of SS in sewage deposited at the bottom of the channels and lakes during the flow. Furthermore, the population of these 7 catchments, that discharged the sewage to points 6 to 15 , is $85.3 \%$ of the whole study area population. Consequently, $56 \%$ of SS discharged from the whole study area deposited and retained at the bottom of the channels and lakes. The maximum, minimum and mean values of SS at points 1 to 4 during the rainy season were 42, 14, and $29 \mathrm{mg} / \mathrm{L}$, respectively. Therefore, SS concentrations in rainy season were $32 \%$ of those in dry season. In contrast, SS concentrations at points 7 and 10 to 15 were higher in rainy season than those in dry season. Suspended solids of Mekong River at Phnom Penh in September 1997 and 
December 1997 were 185 and $3 \mathrm{mg} / \mathrm{L}$, respectively (Mekong River Commission, 1997) This organization did not measure the water quality during the latter part of 1998 so the data in September 1997 were used instead of the data in September 1998. In addition, the mean values of SS of surface water in Thailand,

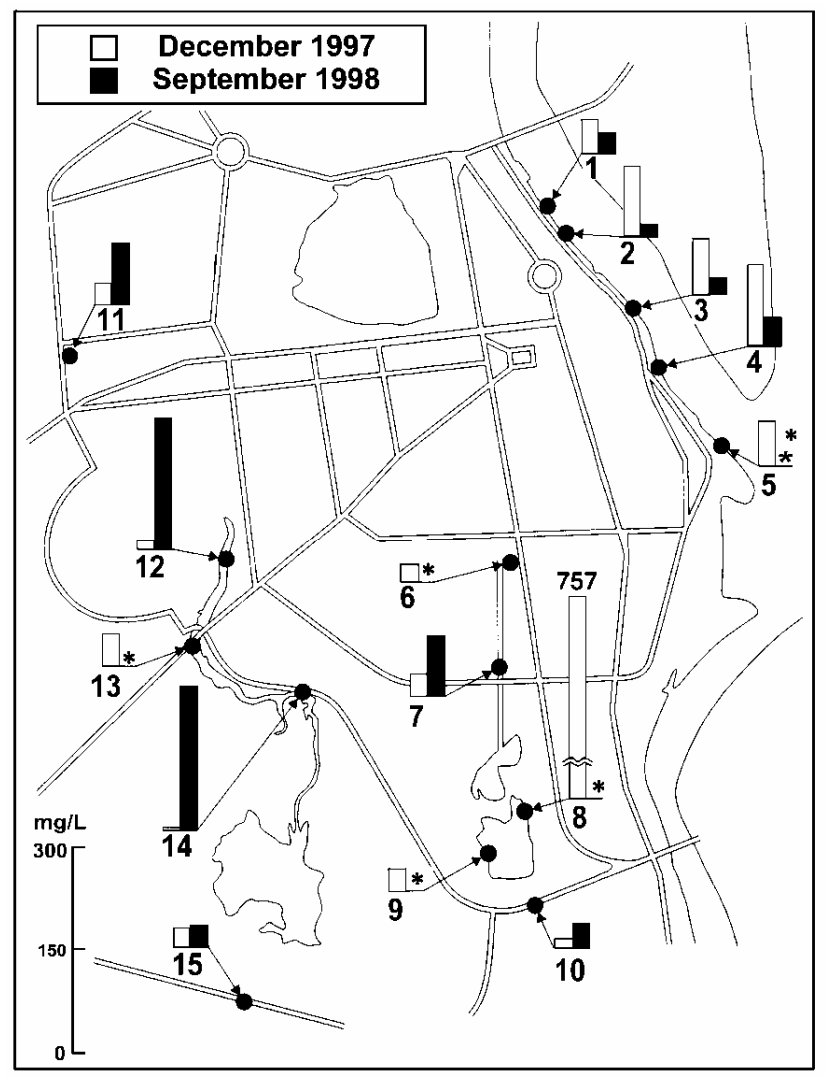

Figure 2. SS in sewage discharged from Phnom Penh

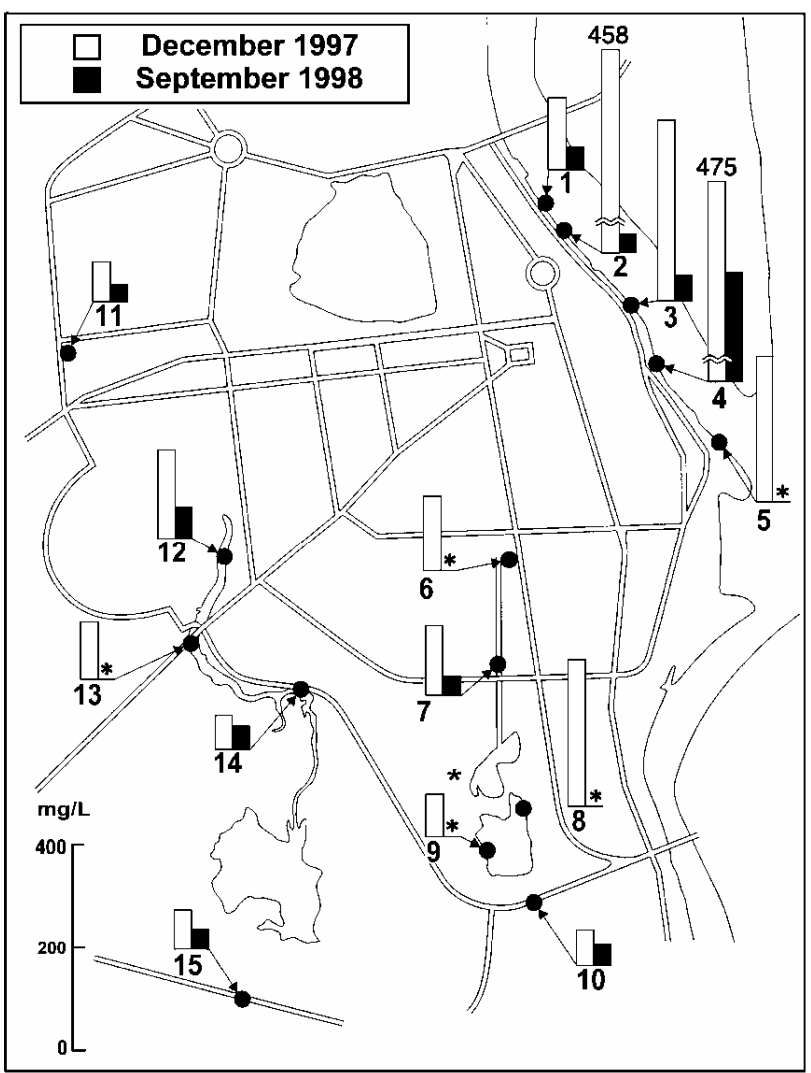

Figure 3. $\mathrm{COD}(\mathrm{Cr})$ in sewage discharged from Phnom Penh

which is the adjacent country of Cambodia, in rainy season and dry season were 240 and $60 \mathrm{mg} / \mathrm{L}$, respectively (Kobayashi, 1958). The SS concentration results in points 1 to 5 were much higher than the SS of Mekong River and surface water in Thailand in dry season. On the other hand, SS in points 1 to 4 were lower than SS of Mekong River and surface water in Thailand in rainy season.

\section{$\operatorname{COD}(\mathrm{Cr}), \mathrm{T}-\mathrm{N}$ and T-P}

The results of $\operatorname{COD}(\mathrm{Cr})$ analysis are shown in Figure 3. Maximum, minimum and mean values of $\mathrm{COD}(\mathrm{Cr})$ in points 1 to 5 in dry season were 475, 142 and $346 \mathrm{mg} / \mathrm{L}$, respectively, while in the other points, except for Point 8, were 155, 67 and $109 \mathrm{mg} / \mathrm{L}$, respectively. High concentration of $\mathrm{COD}(\mathrm{Cr})$ was found in point 8 , presumably due to the deposited suspended matter. The concentrations of $\mathrm{COD}(\mathrm{Cr})$ as well as SS in points 1 to 5 were higher than those of the other points and the correlation coefficient between $\operatorname{COD}(\mathrm{Cr})$ and SS was high in dry season. It can be considered that organic matter in dry season sewage was mainly occupied by suspended organic matter, because it can be presumed that dissolved organic matter was also contained. At all points, the concentrations of $\mathrm{COD}(\mathrm{Cr})$ in rainy season were lower than those of dry season possibly because of the attenuation by rainwater. In rainy season, the concentration of $\operatorname{COD}(\mathrm{Cr})$ in point 4 was slightly higher than those of the other points. It did not rain the night before the sampling day at point 4 . Thus, the sample seemed not to be greatly affected by rainwater. Maximum, minimum and mean values of T-N in dry season were 65 , 23 and $41 \mathrm{mg} / \mathrm{L}$, respectively, and in rainy season were 55, 12 and $18 \mathrm{mg} / \mathrm{L}$, respectively. Maximum, minimum and mean values of T-P in dry season were $9.5,3.3$ and $5.6 \mathrm{mg} / \mathrm{L}$, respectively, and in rainy season were $5.9,1.0$ and $2.0 \mathrm{mg} / \mathrm{L}$, respectively.

The behavior and seasonal variations of T-N and T-P were quite similar to those of $\mathrm{COD}(\mathrm{Cr})$. In addition, positive correlations were found among $\mathrm{COD}(\mathrm{Cr}), \mathrm{T}-\mathrm{N}$ and T-P in both seasons. Therefore, $\mathrm{COD}(\mathrm{Cr}), \mathrm{T}-\mathrm{N}$ and T-P might be derived from the same source. Taking into account the great housing density in Phnom Penh, the pollutants seemed to come from domestic sewage. 
The mean value of $\operatorname{COD}(\mathrm{Mn})$ of surface water in Thailand in dry season and rainy season were 5.1 and 13 $\mathrm{mg} / \mathrm{L}$, respectively (Kobayashi, 1958). The concentration of COD(Mn) in Mekong River at Phnom Penh in September 1997 and December 1997 were 2.2 and $1.4 \mathrm{mg} / \mathrm{L}$, respectively, and T-P of Mekong River at Phnom Penh in September 1997 and December 1997 were 0.03 and 0.02 mg/L, respectively (Mekong River Commission, 1997). The concentration of COD in Mekong River and surface water in Thailand was measured using $\mathrm{KMnO}_{4}$ as an oxidant while $\mathrm{COD}$ was measured using $\mathrm{KCr}_{7} \mathrm{O}_{4}$ in this study. Despite the low oxidizing ability of $\mathrm{KMnO}_{4}$, organic matter in sewage discharged from Phnom Penh was higher than that of Mekong River and surface water in Thailand in rainy season.

\section{Anionic Surfactant (AS) and Non-ionic Surfactant (NS)}

Anionic surfactant (AS) was detected from all samples in both seasons. Non-ionic surfactant (NS) was also detected from all samples in dry season but it was detected from 6 out of 10 samples in rainy season (Table 1). Maximum, minimum and mean values of AS were $17,2.5$ and $8.2 \mathrm{mg} / \mathrm{L}$ in dry season. The behavior and seasonal variations of AS and NS were quite similar to those of COD, T-N and T-P. In addition, AS and NS had a positive correlation with COD, T-N and T-P. Therefore, AS and NS, as well as COD, T-N and T-P, seemed to come from domestic wastewater. The concentration of methylene blue-active substances (MBAS) in influent of sewage treatment plants in eight main cities in Japan ranged from 0.66 to $8.6 \mathrm{mg} / \mathrm{L}$ (Japan Soap and Detergent Association, 1997). Thus, the AS levels of sewage from Phnom Penh seemed to be higher than those from main cities of Japan because the results of MBAS had positive interferences due to the presence of all non-surfactant MBAS. Maximum, minimum and mean values of NS in sewage from Phnom Penh were $5.1,0.1$ and $1.4 \mathrm{mg} / \mathrm{L}$, respectively, in dry season and $0.9, \mathrm{ND}$ and $0.32 \mathrm{mg} / \mathrm{L}$, respectively, in rainy season. The NS levels of rivers in Japan, which received sewage from residential area, were 0.005 to $1.16 \mathrm{mg} / \mathrm{L}$ (Setsuda, 1982; Setsuda et al. 1982). Thus, NS level of sewage water from Phnom Penh City was similar to the river in the cities of Japan.

\section{Total Organic Halogens}

The results of total organic halogens (TOX) are shown in Table 1. Unlike COD, T-N and T-P, high concentration of TOX was found at points 2, 3, 4, 10, 12 and 15. Especially, 20,700 $\mu \mathrm{g} / \mathrm{L}$ of TOX was found in Point 4. These results suggested that there were occasional specific TOX sources in the study area. Small factories and workshops that discharged the wastewater directly to the sewer, ditch, channel and lake, existed in the study area. These factories might be one of the pollutant sources.

\section{Bisphenol-A}

The results of Bisphenol-A (BPA) analysis are shown in Figure 4. In all samples collected in both seasons, BPA was detected. Maximum, minimum and mean values of BPA in dry season were $0.185,0.015$ and 0.081 $\mu \mathrm{g} / \mathrm{L}$, respectively, and in rainy season were $0.660,0.020$ and $0.158 \mu \mathrm{g} / \mathrm{L}$, respectively. High concentrations of BPA were found in rainy season samples from several points. BPA showed moderate correlation with COD, T-N and T-P in dry season while it did not show correlation with other indicators except for NS in rainy season. There might be specific BPA pollutant sources in the study area. Maximum, minimum and mean values of BPA in influent of sewage treatment plants in Japan were 5.3, 0.09 and $0.53 \mu$ $\mathrm{g} / \mathrm{L}$, respectively, (Ministry of Construction, Japan, 1999) while 0.009-0.438 $\mu \mathrm{g} / \mathrm{L}$ of BPA was detected from surface water in Japan (Shindo et al. 1998). Therefore, water pollution by BPA had already spread in Phnom Penh and the level of BPA in sewage from Phnom Penh was slightly lower than that of Japan.

\section{Heavy Metals in Sewage}

The results of $\mathrm{Cd}$ analysis are shown in Figure 5. Cd concentrations at points 1 to 5 (especially in point 5 where $\mathrm{Cd}$ concentration was found to be $5.1 \mu \mathrm{g} / \mathrm{L}$ ) were higher than the other points in dry season. The concentrations of other metals, except for $\mathrm{Mg}$ and $\mathrm{Mn}$, in point 5 were also higher than those of the other points. This suggests that there was a major metal source around point 5 (Trabek 2 catchment). Generally, Cd levels in rainy season were higher than those in dry season, especially in points 7, 10, 11, 12 and 14. Similar tendency was found in $\mathrm{Cr}, \mathrm{Pb}, \mathrm{Zn}$ and Fe metals. As previously mentioned, SS showed a similar behavior and high correlation coefficients were found between SS and these metals. Therefore, high concentrations of heavy metals in rainy season are related to high levels of SS. 


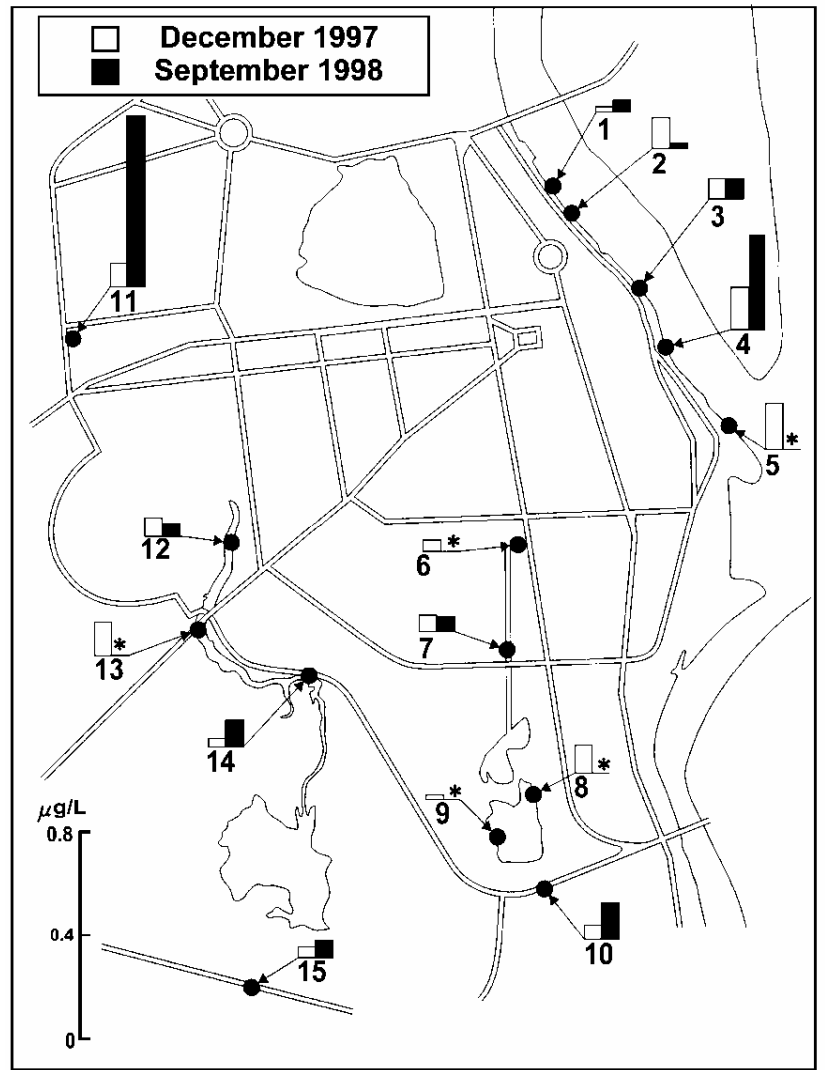

Figure 4. Bisphenol-A in sewage discharged from Phnom Penh

\section{Volatile Total Solid and Heavy Metals in Sediments}

The results of VTS and heavy metal analyses in sediments are summarized in Table 3. The VTS levels at points 6 to 15 were higher than those of points 1 to 5 . In points 8,12 and 13, VTS were 13, 15 and $15 \mathrm{mg} / \mathrm{kg}$, respectively. High VTS in these points might be attributed to the organic matter deposited at the bottom of lakes and channels. The correlation coefficients between VTS and SS; Cr; $\mathrm{Cu} ; \mathrm{Pb} ; \mathrm{Zn}$; and $\mathrm{Fe}$ in sewage in rainy season were $0.684,0.706,0.822,0.823$ and 0.633 , respectively. Thus, this suggests that the high levels of SS and heavy metals in sewage in rainy season resulted from the suspension of VTS deposited at the bottom brought about by storm water. Concentrations of $\mathrm{Cd}, \mathrm{Cr}$ and $\mathrm{Pb}$ in sediments are shown in Figure 6. About $1.4 \mathrm{mg} / \mathrm{kg}$ of $\mathrm{Cd}$ was found in sediments of point 5 where high concentrations of heavy metals were also found in sewage. Levels of $\mathrm{Cd}$ in points 8, 12 and 13 were $0.77,0.54$ and $0.68 \mathrm{mg} / \mathrm{kg}$, respectively. High concentrations of $\mathrm{Pb}, \mathrm{Zn}$ and $\mathrm{Cu}$ were also found in these 3 points. Significant difference was not observed in Cr levels among sampling

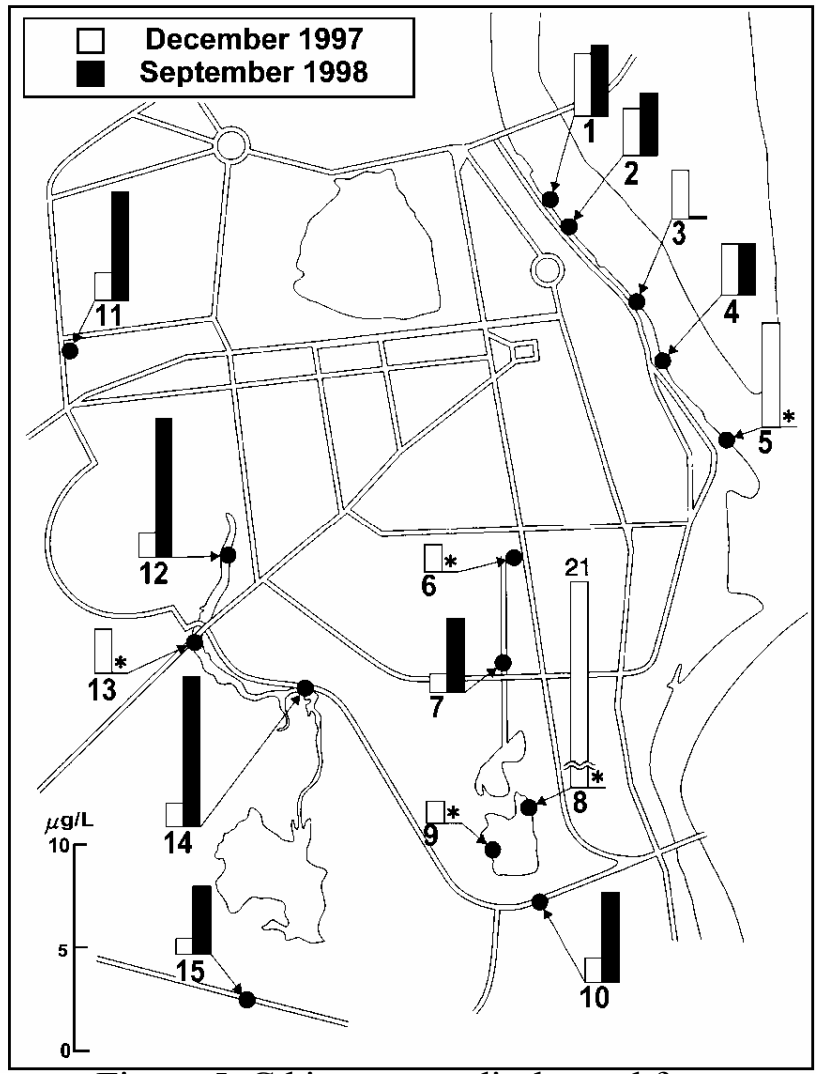

Figure 5. Cd in sewage discharged from Phnom Penh

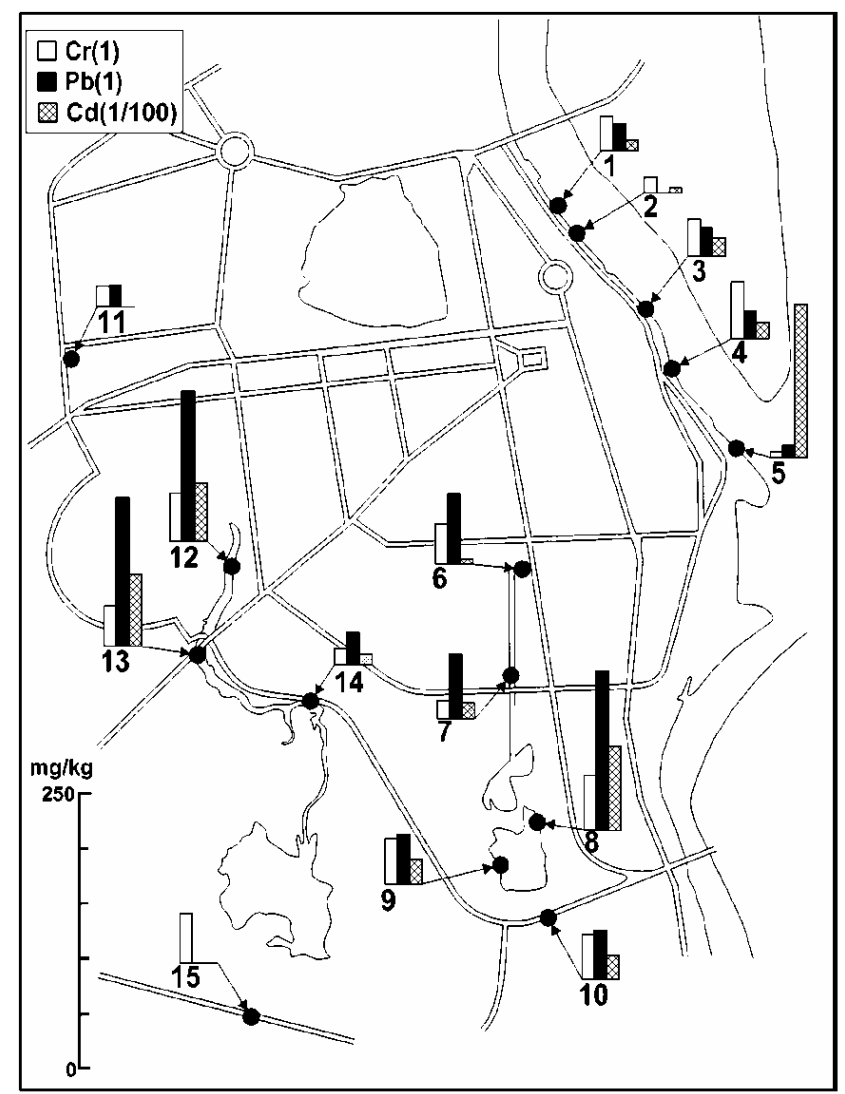

Figure 6. $\mathrm{Cr}, \mathrm{Pb}$ and $\mathrm{Cd}$ in sediments of waterways in Phnom Penh (The real value of $\mathrm{Cd}$ can be obtained from the graph using the ratio $1 / 100$.) 
locations. The levels of heavy metals in sediments in Phnom Penh were compared with those in unpolluted soils and paddy fields reported in other studies (Table 3). The concentrations of these metals in the sediments taken from points 8, 12, and 13 were much higher than those in the unpolluted soil around Phnom Penh. The level of $\mathrm{Cr}$ in sediments was almost similar to those in the unpolluted soil around Phnom Penh and paddy soil in Cambodia.

Table 3. Heavy metal concentration in sediments of waterways in Phnom Penh

\begin{tabular}{|c|c|c|c|c|c|c|c|c|c|c|}
\hline & & VTS & $\mathrm{Fe}$ & $\mathrm{Mg}$ & $\mathrm{Cd}$ & $\mathrm{Pb}$ & $\mathrm{Cu}$ & $\mathrm{Zn}$ & $\mathrm{Mn}$ & $\mathrm{Cr}$ \\
\hline \multirow{4}{*}{$\begin{array}{c}\text { Sediment in } \\
\text { Waterways in Phnom } \\
\text { Penh } n=15\end{array}$} & Max & 15 & 4.6 & 17,927 & 1.4 & 146 & 128 & 758 & 1015 & 53 \\
\hline & Min & 2.1 & 0.7 & 19 & N.D. & N.D. & 16 & 3 & 80 & 6 \\
\hline & Mean & 7.4 & 3.0 & 3,785 & 0.31 & 52 & 47 & 227 & 384 & 33 \\
\hline & $\sigma$ & 4.0 & 1.1 & 4,314 & 0.39 & 50 & 35 & 243 & 268 & 15 \\
\hline \multirow{4}{*}{$\begin{array}{c}\text { Unpolluted Soil } \\
\text { around Phnom Penh } \\
\qquad(\mathrm{n}=3)^{*}\end{array}$} & Max & NA & NA & NA & 0.166 & 26.3 & 37.7 & 56.5 & $\mathrm{NA}$ & 43 \\
\hline & Min & NA & NA & NA & 0.033 & 9.47 & 12.2 & 20.8 & NA & 38 \\
\hline & Mean & NA & NA & NA & 0.103 & 17.2 & 21.1 & 35.3 & NA & 40 \\
\hline & $\sigma$ & NA & NA & NA & 0.067 & 8.5 & 14.4 & 18.8 & NA & 3 \\
\hline \multirow{4}{*}{$\begin{array}{c}\text { Paddy Field in } \\
\text { Cambodia }(\mathrm{n}=16)^{* *}\end{array}$} & Max & NA & NA & NA & NA & NA & 105 & 87 & NA & 304 \\
\hline & Min & NA & NA & NA & NA & NA & 15 & 0 & NA & 67 \\
\hline & Mean & NA & NA & NA & NA & NA & 47 & 35 & NA & 127 \\
\hline & $\sigma$ & NA & NA & NA & NA & NA & 28 & 32 & $\mathrm{NA}$ & 56 \\
\hline
\end{tabular}

Unit: $\mathrm{mg} / \mathrm{kg}$ (dry base) except VTS (\%) and Fe (\%)

*: Agusa et al. 2001, **: Domingo et al. 1983

\section{Estimation of the Pollution Load in Phnom Penh}

The unit of pollution load was estimated. The data obtained from the analyses of points 1 to 5 in dry season were used for the estimation because the sewage in these points in dry season could be regarded as dry weather sewage. Generally, variation in sewage flow and pollutant load of domestic wastewater has its peak at breakfast time and when washing clothes in the morning (Kamada et al, 1980; Urano et al, 1983; Matsui et al, 1987). During this period, $47 \%$ of the daily sewage flow, $47 \%$ of COD and $59 \%$ of MBAS were discharged(Urano et al, 1983). In this study, sampling was carried out between 9:00 and 10:00am. It was observed that in general, clothes are washed in the morning in Phnom Penh. In estimating the unit of pollutant load, it was assumed that $47 \%$ of the daily sewage flow, $47 \%$ of COD, T-N, T-P, and SS and $59 \%$ of surfactants were discharged during the sampling period. One hundred sixty liters of sewage flow per person a day, which is $90 \%$ of the average water consumption obtained from the survey conducted in September 1997, was used as basis. The pollution loads obtained from three catchments are shown in Table 4. The general pollution load (Japan Sewage Works Association, 1994) and the pollution load obtained from several studies in Japan (Kamada et al, 1980; Urano et al, 1983; Matsui et al, 1987) are also shown in Table 4. The pollutant loads in three catchments were almost at the same level. The mean values of pollutant loads of SS, COD, T-N, T-P, AS and NS in three catchments were 13, 53, 8.2, 1.1, 1.4 and 0.3 (g/person-day), respectively. Compared to the pollutant load in Japan, those of T-N, T-P and AS in Cambodia were nearly

Table 4. Pollution load per capita per day in Phnom Penh

\begin{tabular}{cccccccccc}
\hline & & $\begin{array}{c}\text { Sewage } \\
\text { Volume }\end{array}$ & SS & COD & T-N & T-P & $\begin{array}{c}\text { Anionic } \\
\text { Surfactant }\end{array}$ & $\begin{array}{c}\text { Nonionic } \\
\text { Surfactant }\end{array}$ \\
\hline \multirow{5}{*}{ Phnom Penh } & Don Penh & 160 & 12 & 47 & 5.6 & 1.0 & 1.2 & 0.3 \\
& Trabek 1 & 160 & 16 & 65 & 9.9 & 1.2 & 1.9 & 0.4 \\
& Trabek 2 & 160 & 10 & 46 & 9.1 & 1.1 & 1.0 & 0.2 \\
\cline { 2 - 9 } & Average & & 13 & 53 & 8.2 & 1.1 & 1.4 & 0.3 \\
\hline \multirow{3}{*}{ Japan } & General* $^{*}$ & - & 45 & 27 & 11 & 1.3 & - & - \\
\cline { 2 - 9 } & References** $^{*}$ & $160 \sim 280$ & $14 \sim 45$ & $12 \sim 23$ & $1.4 \sim 6.7$ & $0.23 \sim 1.2$ & $1.2 \sim 3.3$ & $0.5 \sim 3.3$ \\
\hline
\end{tabular}

Units : g/person/day, Sewage Volume: L/person/day

*: Japan Sewage Works Association, 2001 , **: Kamada et al, 1980; Urano et al, 1983; Matsui et al, 1987 
similar. The pollutant load of COD in Cambodia was higher than that in Japan. The main reason for high COD pollution load in Cambodia was the difference of the oxidizing abilities between $\mathrm{KMnO}_{4}$ and $\mathrm{KCr}_{7} \mathrm{O}_{4}$. In the studies conducted in Japan, $\operatorname{COD}(\mathrm{Mn})$ was used while $\mathrm{COD}(\mathrm{Cr})$ was used in this study. On the other hand, the reason for high SS pollution load in Phnom Penh was unclear.

\section{CONCLUSION}

In order to evaluate the quality of sewage from Phnom Penh City, the sewage water quality was investigated from December 1997 to September 1999. The following findings were obtained in this study.

1. The sewage discharged from central Phnom Penh contained high concentrations of organic matter, total nitrogen and total phosphorus. These compounds came from domestic wastewater.

2. Most water quality indicators in rainy season were lower than those in dry season due to the attenuation caused by rainwater. Concentrations of SS and heavy metals in sewage taken from the channels, lakes and pumping stations, however, increased in rainy season.

3. Pollution by synthetic organic compounds such as anionic surfactant, nonionic surfactant, total organic halogens and Bisphenol-A already spread in Phnom Penh City. In particular, the level of both surfactants in sewage from Phnom Penh was similar to that of Japan.

4. Domestic wastewater was the source of anionic and nonionic surfactants. The sources of total organic halogens, and Bisphenol-A were sporadically located in Phnom Penh City.

5. Organic matter and heavy metals deposited at the bottom of the channels and lakes. The levels of $\mathrm{Cd}, \mathrm{Pb}$, $\mathrm{Cu}$ and $\mathrm{Zn}$ at these points were higher than those in unpolluted soils in Cambodia. The deposited SS and heavy metals were flushed outside the central Phnom Penh by storm water in rainy season.

6. The pollutant loads of SS, COD, T-N, T-P, and anionic and nonionic surfactants are 13, 53, 8.2, 1.1, 1.4 and 0.3 (g/capita/day), respectively.

This study was carried out in the late 90's, but the sewage discharge system in Phnom Penh City has not been changed since then. Therefore, the sewage water quality is thought to be unimproved. Sediment pollution had been found in a specific area and it may spread according to the extent of economic and industrial development. In addition, observations revealed that a small food chain is formulated in and around Phnom Penh so emission control and continuous monitoring system should be established and implemented as soon as possible.

\section{ACKNOWLEDGMENTS}

Appreciation is extended to the Ministry of Environment and Municipality of Phnom Penh for the aid in sample collection and information gathering; and to Shanty Volunteer Association (SVA) for the kind assistance in carrying out a field survey. This study was supported by Toyota Foundation and Japan Fund for Global Environment.

\section{REFERENCES}

Agusa T., Kunito T., Monirith I., Tanabe S., and Tana T. S.(2002) Contamination by trace elements in dumping sites for municipal wastes in Phnom Penh, Cambodia., Cambodia Environmental Research Group Final report to TOYOTA Foundation (in Japanese)

Asia Development Bank (1997). Cambodia Urban Environmental Improvement Project Interim Report, Asia Development Bank, Cambodia

Domingo L.E. and Kyuma K(1983) Trace elements in tropical asian paddy soils 1- Total trace elements status, Soil Sci. and Plant Nutr. Vol. 29. No. 4, 439-452

Environment Agency (1998). Endocrine Disrupting Chemicals Interim Investigation Manual (Water, Sediment, and Aquatic Organisms), Environment Agency, Japan

Hide S., Hiroshi G., and Yukio T. (1998) Elution of Bisphenol-A from food trays made of Polycarbonate resin and presence of it in environmental waters of Niigata prefecture, 7th Symposium on Environmental Chemistry Program and Abstracts, $72-73$ (in Japanese)

Isao Y. (1980), Influence of synthetic detergents on the pollution of Lake Inba-numa, YOUSHI TO HAISUI, 
Water and Waste Water, Vol.22, No. 4, p.450 459 (in Japanese)

Japan International Cooperation Agency (1998). The Study on Drainage Improvement and Flood Control in the Municipality of Phnom Penh, Japan International Cooperation Agency

Japan Sewage Works Association (1997). Sewage Water Testing Methods in Japan, Japan Sewage Works Association, Japan (in Japanese)

Japan Sewage Works Association (1994). Guideline for Planning and Design in Sewerage Systems, Japan Sewage Works Association, Japan (in Japanese)

Japan Soap and Detergent Association (1997) KANKYOU NENPOU, Annual Environmental Report Vol. 22, Japan Soap and Detergent Association, Japan (in Japanese)

Jun K. (1958) Chemical studies on river waters of south-eastern Asian countries-The nature of waters of Thailand-., Agri. Res., Okayama Univ. Japan, Vol. 46, No. 2, 63-112(in Japanese)

Kouhei U. Masaoka K. Masaaki S., Sachiko H., Junichi K., and Kenjiro Y. (1983) Pollution loads of detergents from household sewage, Japan Jour. of Wat. Pollut. Res., Vol. 6, No.5, 311-318 (in Japanese)

Low, K. S. and G. Balamurugan (1991) Urbanization and urban water problems in Southeast Asia, J. Envir. Manage., Vol. 32, 195-209

Masami M., Sumio H., and Yuhei. N.(1987), The per capita loading of gray water, YOUSHI TO HAISUI, Water and Waste Water, Vol.29, No.2, p.144-149 (in Japanese)

Ministry of Construction (2000). Interim Report of FY 1999 Fact-finding Study on Endocrine Disruptors in the Sewage System in Japan, Ministry of Construction, Japan (in Japanese)

Ministry of Environment (1994). Cambodia First State of The Environment Report 1994, Ministry of Environment, Cambodia

Ministry of Planning (1998). The General Population Census Cambodia 1998, Ministry of Planning, Cambodia

Mekong River Commission (1998). Lower Mekong Hydrologic Yearbook 1997, Mekong River Commission, Lao PDR

Setsuko S., Yasuaki M., Kazuo H., and Syoji N. (1982), The distribution of polyxyethylene nonionic surfactants in river waters in Kanagawa prefecture, Japan Jour. of Wat. Pollut. Res. Vol. 5, No.1, 1-7(in Japanese)

Setsuko K. (1982) Determination of nonionic surfactants in river water in Nagoya city., Annual report of Nagoya city pollution control institution, Vol. 12, 83-87(in Japanese) 